\title{
Do bronchial biopsies represent mast cell density in airways? A stereological study
}

\author{
M.L. Carroll**\#, N.G. Carroll ${ }^{\#}$ and A.L. James ${ }^{\#}$
}

\begin{abstract}
Endobronchial biopsy specimens may not adequately represent inflammatory cell counts throughout the airway wall. The present study aimed to compare mast cell density in biopsies and airway sections using both stereological and nonstereological methods.

Post mortem biopsies and adjacent transverse sections were obtained from a mean of five proximal airways per case in 10 subjects who had died of nonrespiratory causes. Tryptasepositive mast cells were measured stereologically in $30-\mu \mathrm{m}$ sections and nonstereologically in $5-\mu \mathrm{m}$ sections using an optical disector (cells $\mathrm{mm}^{-3}$ ) and cell profiles (cells $\cdot \mathrm{mm}^{-2}$ ), respectively. Reference areas included the inner and total airway wall and to $100 \mu \mathrm{m}$ below the basement membrane.
\end{abstract}

Case means, based on four or more biopsy sites, significantly correlated with those on transverse sections for counts over the inner airway wall only, using both stereological and nonstereological methods. Cells $\mathrm{mm}^{-3}$ and cells $\mathrm{mm}^{-2}$ were significantly correlated within all reference areas.

When endobronchial biopsies are obtained from at least four proximal airways per case, intersubject comparisons of mean mast cell density in the inner airway wall are as well represented by counts on biopsies as they are on transverse sections. This is the case using either threedimensional, stereological or two-dimensional, nonstereological methods.

KEYWORDS: Asthma, biopsy, inflammation, stereology

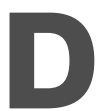
evelopment of the flexible fibreoptic bronchoscope in 1967 [1], followed by the resolution of concerns about the safety of its use [2], led to an acceleration in the use of endobronchial biopsy to examine inflammation in the airways of patients with asthma. Since the mid 1980s, the perceived success of endobronchial biopsies in demonstrating submucosal inflammation and the effects of treatment [3-16], plus the limitations or complications of indirect methods [10, 17, 18], have helped consolidate bronchial biopsy as the "gold standard" for investigating airway inflammation in vivo in asthma.

Nevertheless, doubt has remained about the representativeness of biopsies, with several studies suggesting that "biopsy specimens, being small, may not be "valid" for the airways as a whole" $[6,10,19]$. Concerns about the anatomical sampling limitations of only taking biopsies from carinal sites [20] have added to concerns about the limitations of size, depth and sampling from proximal airways only [21].

Studies examining the density of inflammatory cells in the airways in asthma using airway transverse sections from post mortem tissue sample the bronchial tree more comprehensively than do studies using bronchial biopsies. Since most biopsy studies reporting the density of inflammatory cells have been in mild cases of asthma [3, 4, 6-16, 22], comparisons with post mortem studies are effectively limited to the small number of such studies that have compared transverse sections from cases of less severe, nonfatal asthma and controls $[23,24]$. Results of biopsy studies in mild asthma have not been entirely consistent with either results of the post mortem studies using cases of nonfatal asthma, or with each other.

Another methodological consideration is whether the density of inflammatory cells in endobronchial biopsy specimens should be assessed by means of traditional two-dimensional (2D) "area profile counts" or three-dimensional (3D) "stereology-based" methods [20]. At the centre of this issue is the question of potential bias. Since the probability of a cell's profile appearing in a 2D section is directly related to the cell's size, shape and orientation relative to the cutting plane, there is an inherent risk that area profile counts are biased in favour of certain cells [25, 26].
AFFILIATIONS

*Faculty of Regional Professional Studies, Edith Cowan University, Bunbury, and

${ }^{\#}$ West Australian Sleep Disorders Research Institute, Dept of Pulmonary Physiology, Sir Charles Gairdner Hospital, Nedlands, Western Australia.

CORRESPONDENCE

M. Carroll

Dept of Pulmonary Physiology

Sir Charles Gairdner Hospital

Hospital Avenue

Nedlands

6009 Western Australia

Fax: 61893462034

E-mail: Mark.Carroll@

health.wa.gov.au

Received:

March 152006

Accepted after revision:

June 302006

SUPPORT STATEMENT

This study was funded by Merck, Sharp and Dohme (Sydney, Australia). 
However, 3D approaches render the counts free of such biases as they involve counting cells of interest in 3D volumes to give cells $\cdot \mathrm{mm}^{-3}$. In practical terms, this relies on application of the disector principle [27]. Very few studies of airway inflammation in asthma have adopted stereological approaches [26, 2830] and of these only three have used a disector to enumerate cell density. No such studies appear to have used the optical disector [31-33] in thick sections to measure the density of inflammatory cells in actual 3D space.

What is unclear at this stage is the extent and nature of the relationship (if any) between: 1) estimates of inflammatory cell density obtained from endobronchial biopsies at the carinae with inflammatory cell density across the whole airway wall in the vicinity of the biopsy site; and 2) estimates of inflammatory cell density obtained from samples of these tissues with the use of $3 \mathrm{D}$ compared with the more commonly used 2D approaches.

The aim of the present study was to compare the density of mast cells in endobronchial biopsies and transverse sections of large airways from corresponding sites, using both stereological 3D and nonstereological 2D techniques.

\section{METHODS}

Whole lungs (eight left, two right) were obtained at post mortem from 10 subjects (all male, aged 14-44 yrs) who had died from nonrespiratory causes. Consent for the study of these tissues was obtained from the next of kin and with the approval of the ethics committee of Sir Charles Gairdner Hospital (Nedlands, Western Australia). Medical histories were only available from four subjects and in each case excluded the diagnosis of asthma. Lungs were fixed in inflation with $10 \%$ neutralbuffered formalin at a pressure of $25 \mathrm{cmH}_{2} \mathrm{O}$.

Large airways were biopsied under direct vision at the (sub)carinae using standard cupped biopsy forceps. Following each biopsy, a transverse block 2-3 mm long was cut from one of the airway branches immediately adjacent the biopsy site. This procedure was followed progressively from

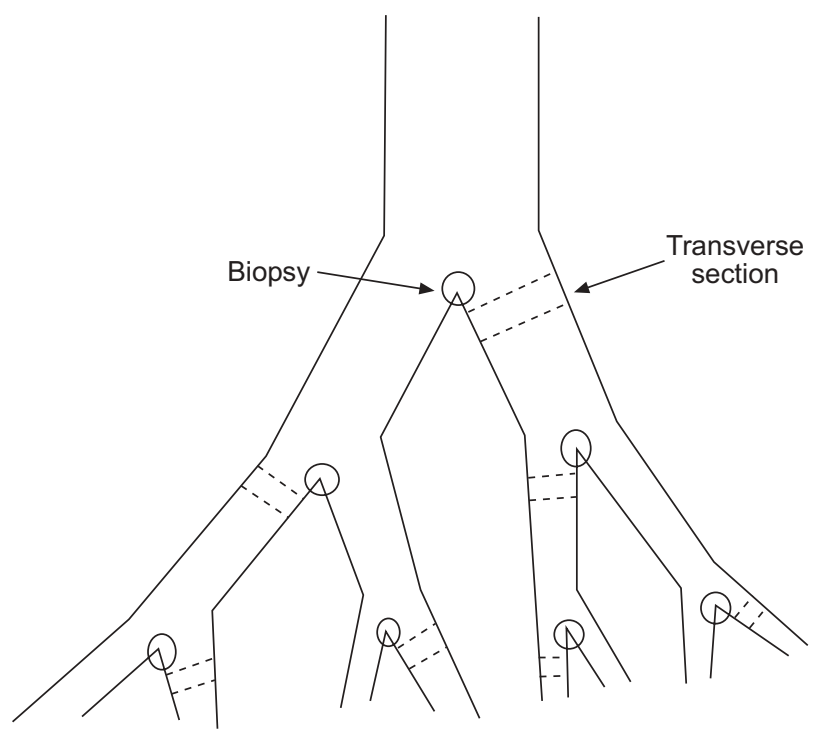

FIGURE 1. Schematic diagram illustrating biopsy and airway dissection protocol in proximal airways. the main lobar bronchi down to fifth or sixth generation airways, taking at least one biopsy and paired transverse block at each level (fig. 1).

For each subject, six biopsies and their paired transverse airway blocks were selected at random from those collected. Each biopsy and transverse airway block was embedded separately in paraffin wax and sections were cut at a thicknesses of both $5 \mu \mathrm{m}$ and $30 \mu \mathrm{m}$. Sections were stained with anti-mast cell tryptase monoclonal antibody AA1 (Dako, Botany, Australia) using the immunoperoxidase technique as previously described [34]. Sections with preparation artefacts were discarded or replaced.

\section{Cell counting}

All cell counts were conducted using the Computer Assisted Stereology Toolbox (CAST) grid $₫$ system (Olympus, Ballerup, Denmark), using an oil immersion lens at $\times 1,000$ magnification and numerical aperture setting of 1.35 to minimise the depth of field. Optimal sampling fractions (i.e. the fraction of the area of interest sampled by uniformly spaced, randomly positioned (UR) fields) of the airway wall compartments were based on pilot counts of mast cells on transverse sections. These were conducted on at least seven seven trial sampling fractions of $1,2,5,10,17$ and $25 \%$.

\section{Estimates of 2D mast cell density in 5- $\mu \mathrm{m}$ transverse airway sections}

Both the inner airway wall (WAi), from the epithelial basement membrane to the outer border of the airway smooth muscle layer, and the total airway wall (WAt), from the epithelial basement membrane to the outer border of the adventitia [35], were delineated on CAST, and, within these reference areas, samples of UR $3,084.3 \mu \mathrm{m}^{2}$ fields comprising $17 \%$ of WAi and $5 \%$ of WAt were generated. These fields were presented sequentially on the high-resolution CAST monitor and positively stained, nucleated cell profiles in focus were counted within a single focal plane with the aid of an unbiased counting frame [36]. The count was repeated on a second, independent sample of UR fields and the mean of the two independent estimates was calculated.

\section{Estimates of 3D mast cell density in 30- $\mu \mathrm{m}$ transverse airway sections using the optical disector}

The optical disector uses a probe that is a predetermined sampling volume within the tissue of interest. The upper and lower borders are preset to avoid the cut edges of the thick tissue sections, and lateral borders are set to allow convenient sampling, depending on the density of objects to be counted. To allow for deformation during tissue processing, the actual thickness of each nominal $30-\mu \mathrm{m}$-thick section was estimated optically as the difference in the height of the microscope stage (using microcator readings) from where the tissue first came into focus to where the tissue went out of focus. The average of 10 random points within delineated areas was calculated. Guard areas $4-\mu \mathrm{m}$ and $5-\mu \mathrm{m}$ thick were established at the top and bottom of each section respectively (fig. 2), with the balance of the section's mean thickness being set as the height of the optical disector probe. This resulted in an average disector height of $17 \mu \mathrm{m}$. Further guard areas $14-18-\mu \mathrm{m}$ wide were established around the sides of the disector. 
Surface of cover slip

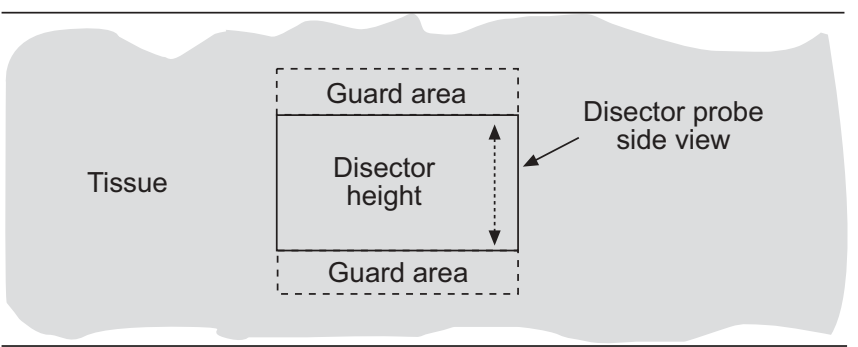

Surface of microscope slide

FIGURE 2. Schematic side view of the optical disector showing the guard areas above and below disector probe (not to scale).

To count positively stained cells appearing in a field, the focal plane with its associated unbiased counting frame was scanned slowly down through the tissue. Cells first coming into focus within the disector height were counted provided that they fell entirely within the counting frame or only touched its acceptance lines and not its forbidden lines (fig. 3).

Within each airway section, the number density $(\mathrm{Nv})$ of mast cells $\left(\right.$ cells $\cdot \mathrm{mm}^{-3}$ ) was estimated for WAi and WAt by:

$\mathrm{N}_{\mathrm{v}}=\left(10^{9} \Sigma \mathrm{Q}\right) /($ a.h. $\Sigma \mathrm{P})$

where $\Sigma \mathrm{Q}=$ total number of positively stained cells counted in the sample, $\Sigma \mathrm{P}=$ total number of fields in the sample, a =area of the unbiased counting frame $\left(\mu \mathrm{m}^{2}\right)$, and $\mathrm{h}=$ disector height $(\mu \mathrm{m})$.

\section{Estimates of 2D and 3D mast cell density in endobronchial biopsy sections}

Independent $17 \%$ samples of UR fields were generated over two reference areas; WAi, where definable, and an area to a depth of $100 \mu \mathrm{m}$ below the basement membrane, similar to previous studies $[3,6,7,16]$. $2 \mathrm{D}$ counts in $5-\mu \mathrm{m}$ biopsy sections were conducted as for $5-\mu \mathrm{m}$ transverse sections to give cells $\cdot \mathrm{mm}^{-2}$. 3D cell counts in $30-\mu \mathrm{m}$ biopsy sections were conducted using the optical disector as for $30-\mu \mathrm{m}$ transverse sections to give cells $\cdot \mathrm{mm}^{-3}$.

\section{Data analysis}

Pearson's correlation coefficient was used to test the relationship between mast cell densities in biopsies and mast cell densities in associated airway transverse sections, and the relationship between 2D and 3D counts. Mean r-values, where shown, are Fisher $\mathrm{Z}$ weighted means. Otherwise, where appropriate, data are presented as mean \pm SD. Intraclass correlation coefficients were also used to assess the relationship between comparable counts on biopsies and transverse sections. Differences between comparable biopsy and transverse section counts were assessed by Bland-Altman plots. The effect of the number of biopsies used was also examined by repeating the analyses using data from one to four biopsies. Correlations were with the WAi on all transverse sections. Comparisons of results on biopsies and transverse sections were also made between cases grouped by cell counts obtained on transverse sections. An unpaired t-test was used to assess differences between these groups.
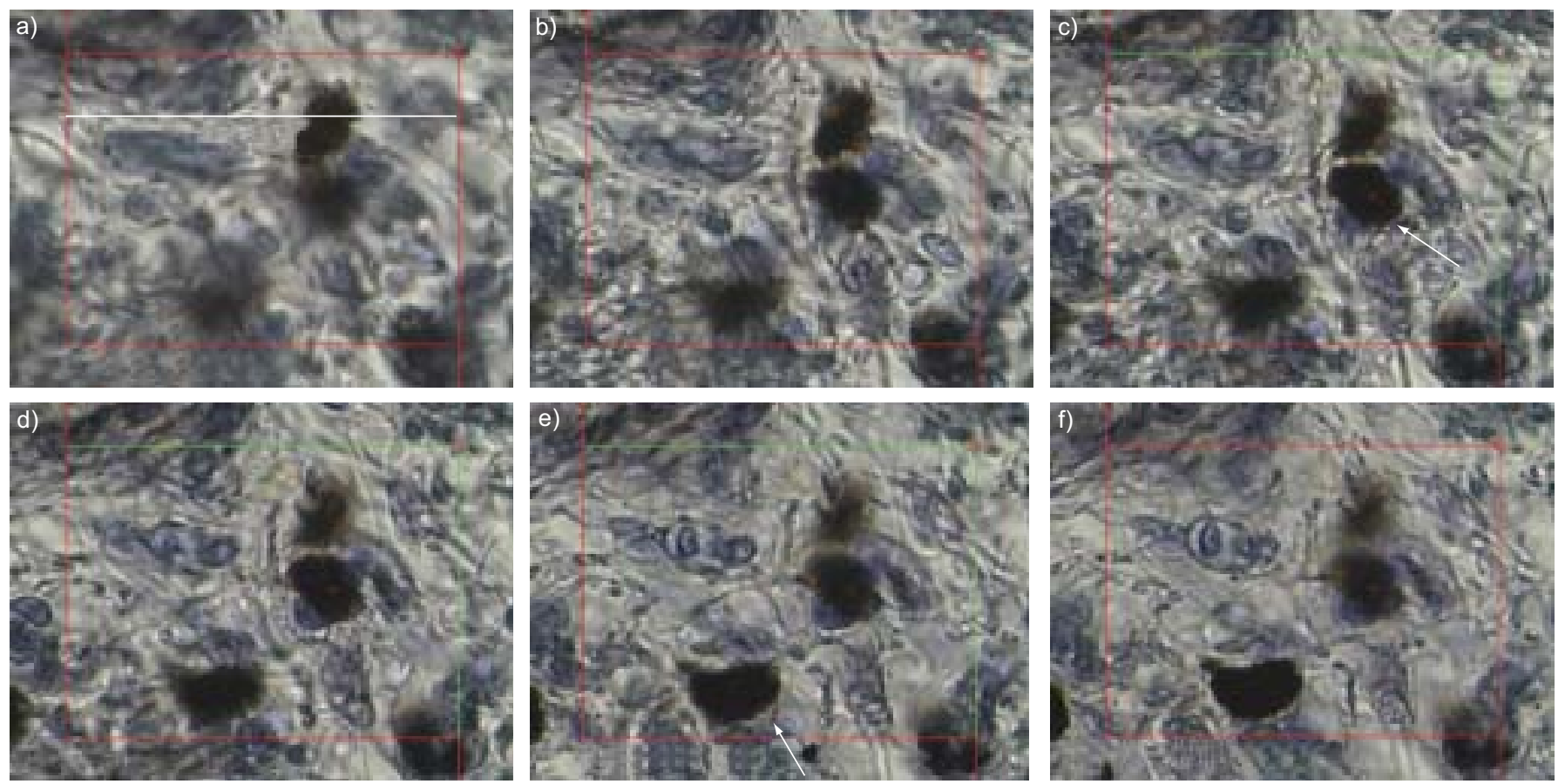

FIGURE 3. Histological staining of positively stained lung tissue cells at a depth of a) $5 \mu \mathrm{m}, \mathrm{b}) 10 \mu \mathrm{m}, \mathrm{c}) 15 \mu \mathrm{m}$, d) $20 \mu \mathrm{m}$, e) $25 \mu \mathrm{m}$, and f) $27 \mu \mathrm{m}$. The size of the counting frame (solid white line) is $64 \mu \mathrm{m}$. The unbiased counting frame is scanned slowly down through the tissue. A cell is counted (arrow) if it first comes into focus within the active disector depth and lies wholly or partly within the frame without crossing the (red) exclusion lines. The disector is active when inclusion lines turn green at the specified tissue depth. 


\begin{tabular}{|c|c|c|c|c|}
\hline \multirow{2}{*}{$\begin{array}{l}\text { TABLE } 1 \\
\text { Biopsies }\end{array}$} & \multicolumn{4}{|c|}{$\begin{array}{l}\text { Intracase correlations of mast cell densities of } \\
\text { biopsies versus transverse sections }\end{array}$} \\
\hline & $\begin{array}{l}\text { Count } \\
\text { type }\end{array}$ & $\begin{array}{l}\text { Transverse } \\
\text { sections }\end{array}$ & $\begin{array}{l}\text { Count } \\
\text { type }\end{array}$ & r-values ${ }^{\#}$ \\
\hline WAi & $2 \mathrm{D}$ & WAi & $2 \mathrm{D}$ & $-0.08(-0.85-0.91)$ \\
\hline WAi & $2 \mathrm{D}$ & WAt & $2 \mathrm{D}$ & $0.09(-0.38-0.45)$ \\
\hline $100-\mu \mathrm{m}$ deep & $2 \mathrm{D}$ & WAi & $2 \mathrm{D}$ & $-0.02(-0.58-0.54)$ \\
\hline $100-\mu \mathrm{m}$ deep & $2 \mathrm{D}$ & WAt & $2 \mathrm{D}$ & $0.07(-0.42-0.92)$ \\
\hline WAi & $3 \mathrm{D}$ & WAi & $3 \mathrm{D}$ & $0.23(-0.95-0.99)$ \\
\hline WA $i$ & $3 \mathrm{D}$ & WAt & $3 \mathrm{D}$ & $-0.33(-0.93-0.48)$ \\
\hline $100-\mu \mathrm{m}$ deep & $3 \mathrm{D}$ & WAi & $3 \mathrm{D}$ & $0.32(-0.39-0.99)$ \\
\hline $100-\mu \mathrm{m}$ deep & $3 \mathrm{D}$ & WAt & $3 \mathrm{D}$ & $0.37(-0.97-0.78)$ \\
\hline WAi & $2 \mathrm{D}$ & WAi & $3 \mathrm{D}$ & $0.15(-0.54-0.65)$ \\
\hline WAi & $2 \mathrm{D}$ & WAt & $3 \mathrm{D}$ & $-0.03(-0.79-0.62)$ \\
\hline $100-\mu \mathrm{m}$ deep & $2 \mathrm{D}$ & WAi & $3 \mathrm{D}$ & $-0.03(-0.79-0.89)$ \\
\hline $100-\mu \mathrm{m}$ deep & $2 \mathrm{D}$ & WAt & $3 \mathrm{D}$ & $-0.06(-0.85-0.93)$ \\
\hline WA $i$ & $3 \mathrm{D}$ & WAi & $2 \mathrm{D}$ & $0.22(-0.72-0.92)$ \\
\hline WAi & $3 \mathrm{D}$ & WAt & $2 \mathrm{D}$ & $-0.25(-0.90-0.98)$ \\
\hline $100-\mu \mathrm{m}$ deep & $3 \mathrm{D}$ & WAi & $2 \mathrm{D}$ & $0.18(-0.47-0.70)$ \\
\hline $100-\mu \mathrm{m}$ deep & $3 \mathrm{D}$ & WAt & $2 \mathrm{D}$ & $0.14(-0.42-0.99)$ \\
\hline
\end{tabular}

\section{RESULTS}

Estimates of intra-observer variability for delineation of reference areas were all $<1 \%$. On transverse sections, the mean count areas assessed per section were $1.33 \mathrm{~mm}^{2}$ and 2.13 $\mathrm{mm}^{2}$ for the WAi and WAt, respectively. On biopsies, the mean count areas assessed per section were $0.29 \mathrm{~mm}^{2}$ for the WAi and $0.12 \mathrm{~mm}^{2}$ to a depth of $100 \mu \mathrm{m}$ below the basement membrane.

\section{Relationships between mast cell density in endobronchial biopsies and adjacent airway transverse sections within cases}

Table 1 shows mean intracase correlations between 2D and 3D mast cell densities in individual biopsies, and 2D and 3D mast cell densities in corresponding airway transverse sections taken adjacent to the biopsy site. In general, mean r-values were low, with no consistent relationship between measurements regardless of the airway compartment measured or the type of measurement (2D or 3D) employed.

\section{Relationships between case means of mast cell density in biopsies and adjacent airway transverse sections}

Mean mast cell densities over the WAi in biopsies showed consistent, significant positive correlation with mean mast cell densities over the WAi on airway transverse sections (table 2). There was no systematic difference between comparable biopsy counts and transverse section counts for the WAi and differences were within Bland-Altman 95\% limits of agreement in $>90 \%$ of comparisons. This was irrespective of whether cell counts were carried out in 2D or 3D. However, in general, the biopsy counts were not significantly correlated

\begin{tabular}{|c|c|c|c|c|c|c|c|}
\hline TABLE 2 & $\begin{array}{l}\text { Interc } \\
\text { densi } \\
\text { sectic }\end{array}$ & $\begin{array}{l}\text { se corre } \\
\text { s using } \\
\text { s per }\end{array}$ & $\begin{array}{l}\text { tions } \\
\text { all biop } \\
\text { e }\end{array}$ & $\begin{array}{l}\text { mear } \\
\text { es ve }\end{array}$ & $\begin{array}{l}\text { mast } \\
\text { rsus al }\end{array}$ & $\begin{array}{l}\text { ell } \\
\text { trans }\end{array}$ & verse \\
\hline \multicolumn{2}{|c|}{ Biopsies } & \multicolumn{2}{|c|}{$\begin{array}{c}\text { Transverse } \\
\text { sections }\end{array}$} & \multirow[t]{2}{*}{$r$} & \multirow[t]{2}{*}{$\mathrm{pr}$} & \multirow[t]{2}{*}{ ICC } & \multirow[t]{2}{*}{ picc } \\
\hline Count area & $\begin{array}{c}\text { Count } \\
\text { type }\end{array}$ & $\begin{array}{c}\text { Count } \\
\text { area }\end{array}$ & $\begin{array}{l}\text { Count } \\
\text { type }\end{array}$ & & & & \\
\hline WAi & $2 \mathrm{D}$ & WAi & $2 \mathrm{D}$ & 0.73 & $<0.05$ & 0.75 & $<0.005$ \\
\hline WAi & $2 \mathrm{D}$ & WAi & $3 D$ & 0.70 & $<0.05$ & & \\
\hline WAi & $3 \mathrm{D}$ & WAi & $2 \mathrm{D}$ & 0.83 & $<0.005$ & & \\
\hline WAi & $3 \mathrm{D}$ & WAi & $3 D$ & 0.72 & $<0.05$ & 0.68 & $<0.01$ \\
\hline WA & $2 \mathrm{D}$ & WAt & $2 \mathrm{D}$ & 0.43 & NS & & \\
\hline WAi & $2 \mathrm{D}$ & WAt & $3 D$ & 0.61 & NS & & \\
\hline WAi & $3 \mathrm{D}$ & WAt & $2 \mathrm{D}$ & 0.65 & $<0.05$ & & \\
\hline WAi & $3 \mathrm{D}$ & WAt & $3 D$ & 0.60 & NS & & \\
\hline $100-\mu \mathrm{m}$ deep & $2 \mathrm{D}$ & WAi & $2 \mathrm{D}$ & 0.74 & $<0.05$ & & \\
\hline $100-\mu \mathrm{m}$ deep & $2 \mathrm{D}$ & WAi & $3 \mathrm{D}$ & 0.31 & NS & & \\
\hline $100-\mu \mathrm{m}$ deep & $3 \mathrm{D}$ & WAi & $2 \mathrm{D}$ & 0.63 & NS & & \\
\hline 100- $\mu \mathrm{m}$ deep & $3 \mathrm{D}$ & WAi & $3 D$ & 0.49 & NS & & \\
\hline $100-\mu \mathrm{m}$ deep & $2 \mathrm{D}$ & WAt & $2 \mathrm{D}$ & 0.48 & NS & & \\
\hline $100-\mu \mathrm{m}$ deep & $2 \mathrm{D}$ & WAt & $3 D$ & 0.37 & NS & & \\
\hline $100-\mu \mathrm{m}$ deep & $3 D$ & WAt & $2 \mathrm{D}$ & 0.23 & NS & & \\
\hline $100-\mu \mathrm{m}$ deep & $3 \mathrm{D}$ & WAt & $3 D$ & 0.17 & NS & & \\
\hline
\end{tabular}

r: Pearson correlation coefficient; pr: probability of Pearson r; ICC: intraclass correlation coefficient; pICC: probability of intraclass correlation coefficient; WAi: inner airway wall; $100-\mu \mathrm{m}$ deep: to a depth of $100 \mu \mathrm{m}$ below basement membrane; 2D: two dimensional (cells $\cdot \mathrm{mm}^{-2}$ ); 3D: three dimensional (cells $\cdot \mathrm{mm}^{-3}$ ) WAt: total airway wall; NS: nonsignificant.

with mean mast cell density over the WAt on transverse sections.

Mean mast cell densities to a depth of $100 \mu \mathrm{m}$ below the basement membrane in biopsies showed no consistent, significant correlation with mean mast cell densities over the WAi on airway transverse sections, and no significant correlation with mean mast cell densities over the WAt on airway transverse sections (table 2).

\section{The effect of using one, two, three or four endobronchial biopsies per case}

For the WAi, the density of mast cells based on a single endobronchial biopsy did not correlate with the case mean on transverse sections (table 3). Although mean 2D counts on biopsies showed some significant correlations with case means on airway transverse sections when two or three biopsies were used, correlation coefficients were not consistently significant for both 2D and 3D counts unless at least four biopsies were used to determine the case mean.

\section{Relationship between mean 2D and mean 3D mast cell densities}

In biopsies, mean 2D mast cell density was significantly correlated with mean 3D mast cell density for counts over both the WAi (fig. 4a) and to a depth of $100 \mu \mathrm{m}$ below the basement membrane (fig. $4 \mathrm{~b}$ ). In transverse sections, mean 2D mast cell 


\begin{tabular}{|c|c|c|c|c|c|c|c|c|}
\hline TABLE 3 & $\begin{array}{l}\text { rcase corre } \\
\text { tions }\end{array}$ & s of mast & ensities w & he inner ain & (WA & -4 biop & ersus & yerse \\
\hline \multicolumn{3}{|c|}{ Biopsies } & \multicolumn{2}{|c|}{ Transverse sections } & \multirow[t]{2}{*}{$\mathbf{r}^{\top}$} & \multirow[t]{2}{*}{$\mathrm{pr}$} & \multirow[t]{2}{*}{ ICC } & \multirow[t]{2}{*}{ picc } \\
\hline Number used & Count area & Count type & Count area & Count type & & & & \\
\hline 1 & WAi & $2 \mathrm{D}$ & WAi & 2D & 0.50 & NS & 0.45 & NS \\
\hline 1 & WAi & $3 \mathrm{D}$ & WAi & 2D & 0.35 & NS & & \\
\hline 1 & WAi & $3 \mathrm{D}$ & WAi & $3 \mathrm{D}$ & 0.13 & NS & 0.12 & NS \\
\hline 2 & WAi & $2 \mathrm{D}$ & WAi & $2 \mathrm{D}$ & 0.65 & $<0.05$ & 0.58 & $<0.05$ \\
\hline 2 & WAi & $2 \mathrm{D}$ & WAi & $3 \mathrm{D}$ & 0.60 & NS & & \\
\hline 2 & WAi & $3 \mathrm{D}$ & WAi & $2 \mathrm{D}$ & 0.61 & NS & & \\
\hline 2 & WAi & $3 \mathrm{D}$ & WAi & $3 \mathrm{D}$ & 0.49 & NS & 0.47 & NS \\
\hline 4 & WAi & $2 \mathrm{D}$ & WAi & $2 \mathrm{D}$ & 0.73 & $<0.05$ & 0.73 & $<0.005$ \\
\hline 4 & WAi & $2 \mathrm{D}$ & WAi & $3 \mathrm{D}$ & 0.65 & $<0.05$ & & \\
\hline 4 & WAi & $3 \mathrm{D}$ & WAi & $2 \mathrm{D}$ & 0.82 & $<0.005$ & & \\
\hline 4 & WAi & $3 \mathrm{D}$ & WAi & $3 \mathrm{D}$ & 0.68 & $<0.05$ & 0.68 & $<0.01$ \\
\hline
\end{tabular}

r: Pearson correlation coefficient; pr: probability of Pearson r; ICC: intraclass correlation coefficient; pICC: probability of intraclass correlation coefficient; 2D: two dimensional (cells $\cdot \mathrm{mm}^{-2}$ ); 3D: three dimensional (cells $\cdot \mathrm{mm}^{-3}$ ); Ns: nonsignificant. \#: one randomly selected biopsy per case, or the mean of two, three or four randomly selected biopsies per case, were used; ${ }^{\top}$ : correlations were with case means over the WAi on all transverse sections.

density was significantly correlated with mean 3D mast cell density for counts over both the WAi (fig. 4c) and over the WAt (fig. $4 \mathrm{~d}$ ). In general, 2D and $3 \mathrm{D}$ counts on airway transverse sections were more strongly correlated than 2D and 3D counts on biopsies.

\section{Relative variability of $2 D$ and $3 D$ mast cell densities on endobronchial biopsies and airway transverse sections}

Mean coefficients of variation (CV) in mast cell density were similar for 2D counts and 3D counts (32 and 37\%, respectively), but were significantly smaller for counts on transverse sections than for counts on biopsies (30 and 39\%, respectively). On transverse sections, mean $\mathrm{CV}$ was smaller for counts over the WAi $(23 \%)$ than over the WAt (39\%). On biopsies, mean CV was similar for counts over the WAi (39\%) and to depth of 100 $\mu \mathrm{m}$ below the basement membrane (39\%).

\section{Comparisons between case groups}

The usefulness of biopsies to detect differences between case groups was examined by comparing cases grouped according to mast cell densities in the WAi on all transverse sections. Both 2D and 3D mast cell counts over the WAi on biopsies showed similar significant differences between the groups, as did counts over the WAi on transverse sections (table 4). However, biopsy counts confined to a depth of $100 \mu \mathrm{m}$ below the basement membrane did not show significant differences between the two groups.

\section{DISCUSSION}

Endobronchial biopsy has been widely used as a research tool to assess airway inflammation in asthma [3, 4, 6-16, 22]. Its use as a tool in clinical research has recently become the subject of review [20]. The present study attempted to address the issue of whether endobronchial biopsy specimens provide adequate representation of the distribution of inflammatory cells in the airway wall as a whole. The current study reported a direct comparison of the density of inflammatory cells in endobronchial biopsies and airway transverse sections from the same proximal airways, compared 2D cell profile counts with 3D stereological counts of airway inflammatory cells, and used an optical disector to enumerate the density of airway inflammatory cells in actual 3D space. In addition, it addressed empirically the issue of the minimum number of endobronchial biopsies required to adequately represent the density of inflammatory cells in proximal airways.

The present study found that, for a given case, any single biopsy is unlikely to be representative of mast cell density across the airway wall in the vicinity of the biopsy site or in the proximal airways generally. However, four or more biopsies from different sites can be used to generate a case mean which is likely to be representative of mast cell density across the WAi in proximal airways for the purpose of comparing cases. Both 3D stereological and 2D nonstereological methods of assessing mast cell density in proximal airways resulted in similar conclusions. There was little evidence that intercase comparisons of mast cell density in endobronchial biopsies parallel intercase comparisons of mast cell density across the WAt in proximal airways, or that measurements of mast cell density confined to a depth of $\leqslant 100 \mu \mathrm{m}$ below the basement membrane on endobronchial biopsies can adequately represent mast cell density across the remainder of the airway wall in proximal airways. 


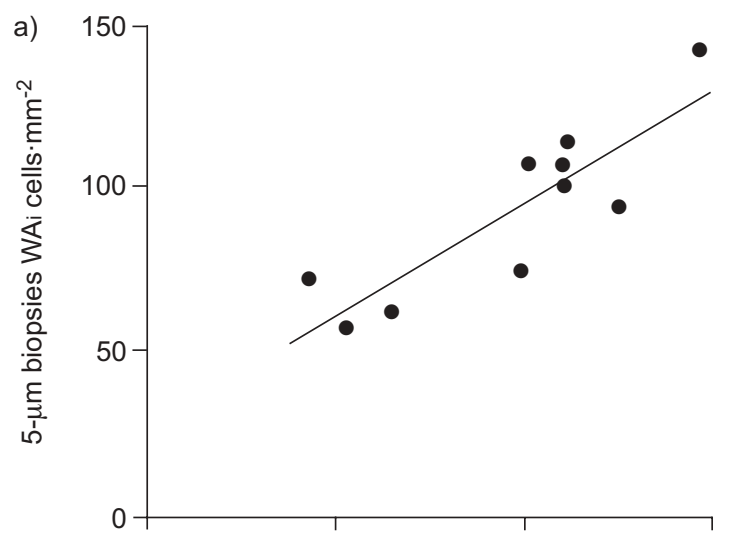

$30-\mu \mathrm{m}$ biopsies WAi cells $\cdot \mathrm{mm}^{-3}$

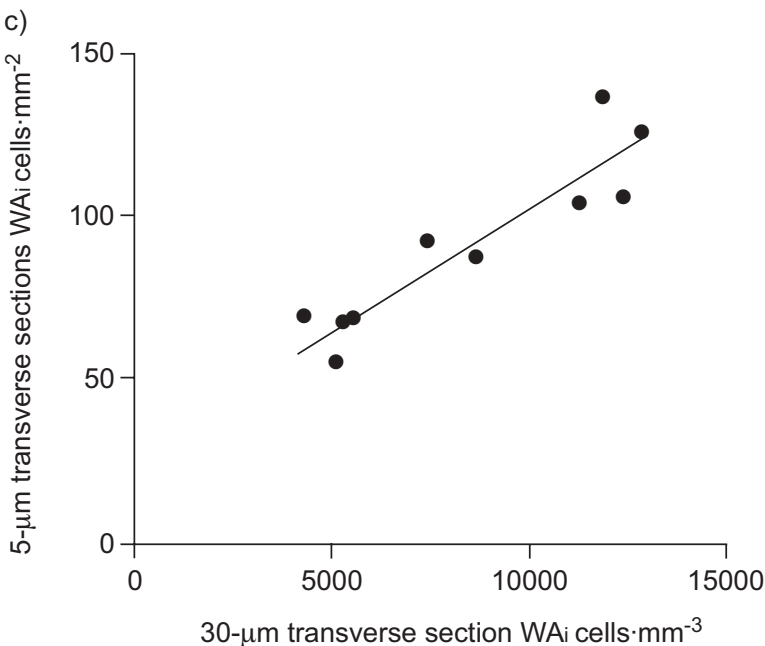

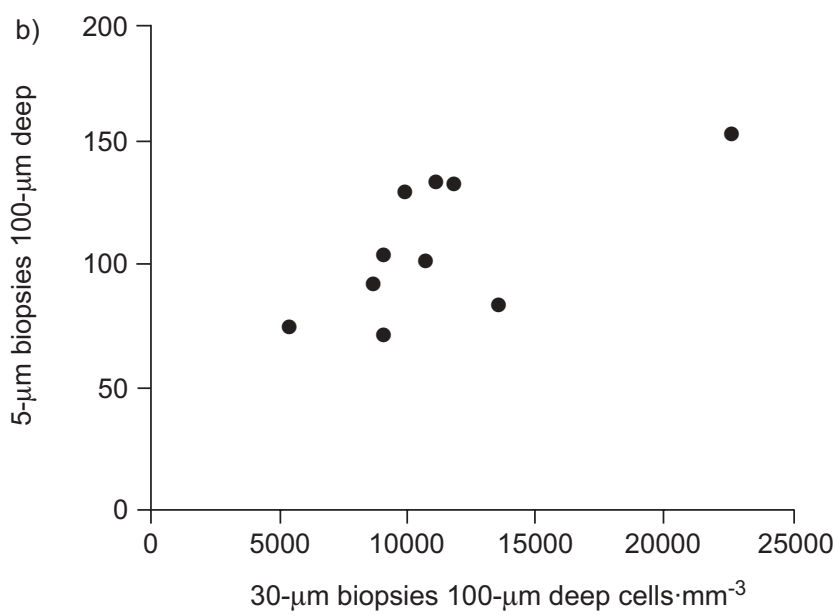

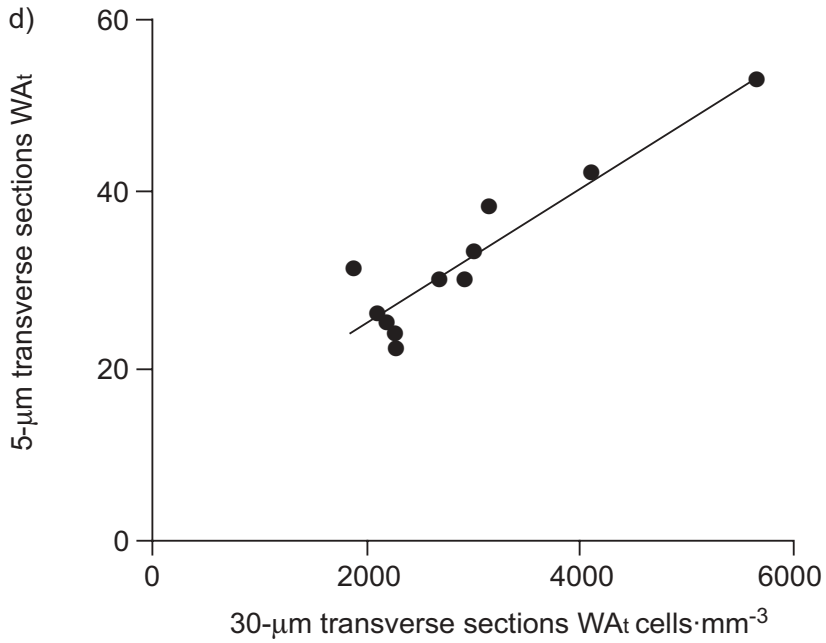

FIGURE 4. Mean two-dimensional mast cell density of 5 - $\mu \mathrm{m}$ biopsies $(\mathrm{a}, \mathrm{b})$ and transverse sections $\left(\mathrm{c}, \mathrm{d}\right.$; cells $\left.\cdot \mathrm{mm}^{-2}\right)$ versus mean three-dimensional mast cell density of $30-\mu \mathrm{m}$ biopsies $(a, b)$ and transverse sections $\left(c, d\right.$; cells $\cdot \mathrm{mm}^{-3}$ ). WAi: inner airway wall; WAt: total airway wall. a) $\left.\left.r=0.86, p<0.005 ; b\right) r=0.68, p<0.05 ; c\right) r=0.92$, $p<0.0005 ;$ d) $r=0.93, p<0.0005$.

\begin{tabular}{|c|c|c|c|c|c|}
\hline TABLE 4 & $\begin{array}{l}\text { Comp } \\
\text { mast } \\
\text { biopsi }\end{array}$ & $\begin{array}{l}\text { son of gro } \\
\text { I densities }\end{array}$ & $\begin{array}{l}\text { ed case } \\
\text { transvers }\end{array}$ & $\begin{array}{l}\text { a usi } \\
\text { sectio }\end{array}$ & $\begin{array}{l}\text { mean } \\
\text { and in }\end{array}$ \\
\hline $\begin{array}{l}\text { Count } \\
\text { area }\end{array}$ & $\begin{array}{l}\text { Count } \\
\text { type }\end{array}$ & $\begin{array}{l}\text { Lower four } \\
\text { cases }\end{array}$ & $\begin{array}{l}\text { Upper six } \\
\text { cases }\end{array}$ & $t$ & $p$-value \\
\hline$X-W A i$ & $2 \mathrm{D}$ & 65 & 108 & 4.252 & $<0.005$ \\
\hline$X-W A i$ & $3 \mathrm{D}$ & 5038 & 10779 & 5.057 & $<0.001$ \\
\hline$B-W A i$ & $2 \mathrm{D}$ & 73 & 106 & 2.447 & $<0.05$ \\
\hline$B-W A i$ & $3 \mathrm{D}$ & 6839 & 11632 & 3.225 & $<0.05$ \\
\hline B-100 $\mu \mathrm{m}$ & $2 \mathrm{D}$ & 92 & 118 & 1.549 & NS \\
\hline $\mathrm{B}-100 \mu \mathrm{m}$ & $3 \mathrm{D}$ & 8309 & 13137 & 1.871 & NS \\
\hline
\end{tabular}

Data are presented as mean cell density, unless otherwise stated. X-WAi: inner airway wall on airway transverse sections; B-WAi: inner airway wall on biopsies; B-100 $\mu \mathrm{m}$ : to a depth of $100 \mu \mathrm{m}$ on biopsies; NS: nonsignificant. \#: data grouped by mean mast cell densities in WAi on transverse sections. Grouping by two-dimensional (2D) counts produced same grouping as by threedimensional (3D) counts, lower four cases versus upper six cases. 2D values are cells $\cdot \mathrm{mm}^{-2}, 3 \mathrm{D}$ values are cells $\cdot \mathrm{mm}^{-3}$.

\section{The use of a single endobronchial biopsy}

A number of biopsy studies of airway inflammation appear to have relied upon the use of a single biopsy specimen [8, 13-15]. In the present study, mean intracase correlations between mast cell density in biopsy sections and adjacent airway transverse sections were very low. This suggests that within a case, any given endobronchial biopsy from a (sub)carina is unlikely to reflect mast cell density across the airway wall generally in the vicinity of the biopsy site. Such a finding is not unexpected given previously observed intrasubject variations in the density of inflammatory cells within sections [37] and between sections $[8,38]$ from the same biopsy site, and between biopsysized segments within an airway section [39].

Furthermore, correlation between mast cell density in one randomly chosen biopsy per case, with the corresponding case mean of mast cell density in airway transverse sections, did not suggest that a single biopsy is likely to adequately reflect mast cell density in the remainder of the bronchial tree for the purposes of intercase comparison. In the current study, single biopsies reflected, at best, $\sim 30 \%$ of the variance in mean mast cell density in the WAi on transverse sections from proximal airways. 
These results are consistent with the finding in a recent study by GAMBLE et al. [40] that sampling more than one airway level is preferable in order to discriminate case groups in chronic obstructive pulmonary disease on the basis of inflammatory cell density in bronchial biopsies.

\section{Case means from multiple endobronchial biopsies}

WAi

The inherent difficulties and potential risks of obtaining multiple biopsies in vivo and the problem of occasional artefactual damage tend to restrict the number of biopsies used in research settings. Biopsy studies of airway inflammation have generally used only two or three biopsies per case to enumerate a particular cell type [3, 4, 6-10, 12-16], and have often relied on 2D cell profile methods, expressing density as cells per area [4, 8-12, 14-16].

The results of the present study indicate a progressive strengthening of the relationship between mast cell counts in the WAi on biopsies and transverse sections as more biopsies are used. Single biopsies reflected $<30 \%$ of the variance in mast cell density in all transverse sections. However, this proportion increased as more biopsies were used to generate a case mean until, using four or more, it was $>50 \%$, ranging upwards to $\sim 70 \%$. Single biopsies were not significantly correlated with transverse sections at all, while the only significant correlation between two biopsies and all transverse sections was confined to $2 \mathrm{D}$ counts in both, which are potentially biased. In contrast, $2 \mathrm{D}$ case means obtained by using three biopsies were significantly correlated not only with 2D counts on transverse sections, but also with 3D counts, which arguably give the best unbiased estimates of cell density for the proximal airways. However, the most consistent results were obtained using four or more biopsies, since mean mast cell densities in the WAi on biopsies and transverse sections were significantly correlated regardless of whether $2 \mathrm{D}$ or $3 \mathrm{D}$ counts were used. These observations are supported by intraclass correlations, which tend to accentuate the differences between using four or more biopsies and fewer than four biopsies.

In essence, the current findings suggest that mast cell density across the WAi in proximal airways is well represented by the mean of four or more biopsies. The mean of two or three biopsies may be adequate, but there is more uncertainty associated with the use of three biopsies than with four or more, and much more uncertainty with two. A single biopsy seems unsatisfactory.

\section{WAt}

However, the results did not indicate that intercase comparisons of mean mast cell density over the WAi on biopsies parallel intercase comparisons of mast cell density over the WAt on transverse sections to a similar degree. Even when using all available biopsies, the resulting case mean generally reflected only $30-40 \%$ of the variance in mean mast cell density over the WAt on transverse sections. In part, this would have been due to greater heterogeneity in the distribution of mast cells over the WAt in proximal airways when compared with the WAi [23], as a result of differences between these compartments in the presence or distribution of structural elements, such as smooth muscle, cartilage plates, submucosal mucous glands and blood vessels.

\section{Cell counts to a depth of $100 \mu \mathrm{m}$ below the basement membrane on endobronchial biopsies}

A number of biopsy studies reporting the density of airway inflammatory cells, including mast cells, have based their results explicitly on cell counts taken to a depth of approximately $\leqslant 100 \mu \mathrm{m}$ below the basement membrane $[3,6,7,16]$. Establishing such a reference area in biopsies is almost always possible as there is usually sufficient countable tissue present, and may be largely a matter of convenience since a $10 \times 10$ eyepiece graticule represents a width of $100 \mu \mathrm{m}$ when using a $\times 100$ objective lens in light microscopy.

The results of the present study did not indicate that intercase comparisons of mean mast cell density based on such a reference area in biopsies parallel intercase comparisons of mast cell density over the WAi generally, or the WAt generally, in proximal airways. Mean mast cell density to a depth of 100 $\mu \mathrm{m}$ below the basement membrane on biopsies reflected, on average, only $\sim 32 \%$ of the variance in mean mast cell density in the WAi on transverse sections, and $\sim 11 \%$ of the variance in the WAt. Comparison of mean mast cell densities based on this reference area in biopsies did not reflect the significant differences between subjects grouped by mean cell density in the WAi.

Mast cells are widely distributed across the WAi, including the smooth muscle layer [23]. Although some authors have implicitly endorsed cell counts in biopsies to a depth of 100 $125 \mu \mathrm{m}$ below the basement membrane, mostly for a variety of other inflammatory cells [40-42], a potential problem with using a narrow band of tissue of fixed absolute width when enumerating mast cells is that it will represent a variable fraction of the width of the WAi at the biopsy site, generally a smaller fraction for larger airways. It may include the smooth muscle layer in the smaller proximal airways, but not in the larger ones. Therefore, it would seem advisable, when counting mast cells within the WAi, to extend the count area to the outer border of the smooth muscle layer. However, while the probability of obtaining "assessable" smooth muscle in an endobronchial biopsy specimen may be $\sim 70 \%$ in segmental airways, it may be much less in the lobar bronchi $[43,44]$.

\section{$2 D$ versus $3 D$ counts}

\section{Some theoretical and practical considerations}

Differences of opinion exist among investigators regarding the relative merits of using $3 \mathrm{D}$ stereological methods compared with 2D nonstereological methods to assess the density of inflammatory cells in airway tissue $[20,45]$. The two methods produce entirely different quantities. The use of uniform randomised sampling and 3D counting in thick histological sections with an optical disector enables a direct and unbiased estimate of the number density of cells within tissues, expressed as cells per unit volume. Conversely, 2D counts provide an indirect indication of the number density of cells, based on cell profiles per unit area. Moreover, as demonstrated recently in a study by FEHRENBACH et al. [26], comparing 2D and 3D quantification of inflammatory cells in bronchial biopsies, such counts may be subject to bias since the 
probability of a cell's profile being included in a thin histological section is proportional to cell height, shape and orientation perpendicular to the plane of the section.

Counting cells in 3D with an optical disector requires the use of relatively sophisticated, specialised and expensive apparatus, such as the CASTgrid ${ }_{\circledast}$ system (Olympus), which was used in the present study. This consisted of: 1) an upright light microscope fitted with a video camera, a microcator and a motorised stage driven by a joystick; 2) an XYZ reader; 3) a computer with a high-resolution monitor; and 4) associated CASTgrid $_{\mathbb{B}}$ software. The actual disector method of counting cells with this equipment is, however, relatively simple (fig. 3). The current authors found that counting cell profiles in 2D was simpler, faster and cheaper than counting in 3D with an optical disector, and by requiring only single thin sections, was more economical in the use of limited biopsy tissue. Thin sections were also less prone to tissue disruption in processing.

Nevertheless, it was found that some features of a stereology workstation could be used to good effect in counting inflammatory cell profiles in 2D, as well as counting in 3D. These included: 1) computerised delineation of the reference area; 2 ) uniform random sampling of the reference area using the meander sampling facility; 3) counting cell profiles with the aid of an unbiased counting frame; 4) viewing serially presented high-power fields $(\times 1,000$ plus $)$ on a high-resolution monitor; 5) use of the navigator facility for easy visualisation of field location within the reference area; 6) marking counted cells with customised icons; and 7) automatic logging of relevant count data.

Use of the above techniques in 2D counts does not rule out the potential bias that is inherent in such counts. However, delineation of reference areas at low magnification, followed by UR sampling and counting with an unbiased counting frame and associated inclusion rules at high magnification, may rule out other subtle biases pertaining to identification and inclusion of cells when relying on more traditional manual "randomisation" of fields and the use of an eyepiece graticule.

\section{Current findings}

As would be expected, 2D and 3D methods produced very different sets of numbers in the present study, with the order of magnitude of mean mast cell densities being mostly $10^{1}$ cells $\cdot \mathrm{mm}^{-2}$ and $10^{3}$ cells $\cdot \mathrm{mm}^{-3}$ for $2 \mathrm{D}$ and $3 \mathrm{D}$ counts, respectively. Nevertheless, corresponding $2 \mathrm{D}$ and $3 \mathrm{D}$ case means displayed very strong positive correlations. This relationship was generally tighter in airway transverse sections where mean $2 \mathrm{D}$ counts reflected, on average, $\sim 86 \%$ of the variance in mean $3 \mathrm{D}$ counts in both the WAi and WAt. In biopsies, mean $2 \mathrm{D}$ counts across the WAi reflected $\sim 74 \%$ of the variance in comparative $3 \mathrm{D}$ counts. In counts to a depth of 100 $\mu \mathrm{m}$ below the basement membrane, this proportion was $\sim 45 \%$.

When all available biopsies were used, both 2D and 3D counts resulted in similar comparisons between case means on biopsies and transverse sections. In these comparisons, the strongest correlations occurred between counts across the WAi, where $2 \mathrm{D}$ and $3 \mathrm{D}$ counts on biopsies were each closely related to both 2D and 3D counts on transverse sections. However, when only three biopsies were used to produce a case mean, the relationship persisted for $2 \mathrm{D}$ counts on biopsies, but not for 3D counts.

It is also notable that when cases were grouped according to means of mast cell density across the WAi on transverse sections, 2D and 3D counts resulted in the same grouping, and that comparisons between these groups were preserved in both $2 \mathrm{D}$ and $3 \mathrm{D}$ counts across the WAi on biopsies.

When comparing 2D with 3D counts from the same reference area on histological sections, the ratio of $\left(\right.$ cells $\left.\cdot \mathrm{mm}^{-2}\right) /$ $\left(\right.$ cells $\cdot \mathrm{mm}^{-3}$ ) provides a rough estimate of the mean cell height, perpendicular to the plane of the section [25]. Averaging this ratio for different count areas across cases gave an estimated mean cell "height" for mast cells of $\sim 11 \mu \mathrm{m}$ in biopsies and $\sim 12 \mu \mathrm{m}$ in transverse sections. These figures are consistent with reported values for the diameters of mast cells in human lung tissue fixed in formalin [46]. Thus, the physical height of the relatively rounded, discrete mast cell accounts for the difference in order of magnitude between 2D and 3D mast cell densities.

\section{Generalisability of the findings}

The present study focused on different methods for estimating inflammatory cell density in proximal airways. Only mast cells were used for comparing these methods. Mast cells were chosen for initial study for four reasons: 1) they are potent and constitutive inflammatory cells long associated with asthma and now the subject of renewed interest [47-49]; 2) they have been shown to stain clearly with the marker for mast cell tryptase employed in the formalin fixed tissues used in the current authors' laboratory; 3 ) their counts have been found to be highly reproducible; and 4) in proximal airways, they are distributed relatively widely across the airway wall, including the smooth muscle layer and mucous glands [23, 44], although their absolute density and level of activation may vary in different compartments and disease states [23].

Unlike many other studies reporting mast cell density in proximal airways, the present study did not compare subjects with known disease (e.g. asthma) and control subjects. It could be argued that cases grouped on the basis of disease are likely to have a much greater range of data than that observed in the current study, and it is therefore possible that fewer biopsies than the average of four suggested here would be sufficient to discriminate case groups. Due to differences in methods of measuring and/or reporting mast cell densities, it is difficult to compare the data from the current study directly with the data from other studies examining mast cell density in proximal airways in disease states. However, in the few instances where a comparison seems possible, the order of magnitude of mast cell densities is similar, while the spread of data values in the present study appears slightly greater than in some studies [12], and slightly less than in others $[8,23]$.

The current results were based on data from only 10 subjects. If it had been possible to use lung tissue from much larger numbers of subjects, it is more likely that case means based on fewer than four biopsies would have been correlated significantly with case means over the WAi in all transverse sections, adding weight to the argument that two or three biopsies could be sufficiently representative of the WAi generally in such circumstances. However, in biopsy studies 
of airway inflammation in asthma, the size of case groups representing disease states is typically of the order of 10 subjects $[3,4,7,8,11,12,15,16,19]$, rarely much more [6], and in the case of control subjects, often much less [4, 7-9, 11, 12]. Furthermore, increasing the number of subjects is unlikely to substantially alter $r$ values, so that while four or more biopsies will probably reflect $>50 \%$ of the variance over the WAi generally, fewer than four biopsies will probably reflect much less.

The results obtained will not necessarily be generalisable to other inflammatory cells, since their distributions vary from that of the mast cell. For example, the density of neutrophils and activated eosinophils in the submucosa is not only much less than that of mast cells $[6,8]$, but their density relative to that of mast cells appears to vary according to sub-compartments, such as mucous glands [34] and airway smooth muscle [50]. Lymphocyte numbers are much higher in the airway wall $[6,24]$ and their density is subject to much greater variability [51]. Furthermore, the mast cell appears to be by far the predominant inflammatory cell within the layer of smooth muscle [52]. Therefore, when counting other inflammatory cells, the inclusion or exclusion of smooth muscle in the measurement area may have a significant effect on overall cell density.

Finally, the density and distribution of inflammatory cells in the small peripheral airways may differ from that observed in the larger proximal airways $[23,24]$. Therefore, the relationship between inflammatory cell density in endobronchial biopsies and that in the remainder of the bronchial tree and throughout the lung requires further study.

\section{ACKNOWLEDGEMENTS}

The authors would like to thank H.J. Gundersen, Stereological Research Laboratory (University of Aarhus, Denmark), and A. Baddeley, School of Mathematics and Statistics (University of Western Australia) for their helpful comments and suggestions.

\section{REFERENCES}

1 Ikeda S, Yanai N, Ishikawa S. Flexible bronchofiberscope. Keio J Med 1968; 17: 1-16.

2 Rankin JA, Snyder PE, Schachter EN, Matthay RA. Bronchoalveolar lavage. Its safety in subjects with mild asthma. Chest 1984; 85: 723-728.

3 Jeffery PK, Wardlaw AJ, Nelson FC, Collins JV, Kay AB. Bronchial biopsies in asthma: an ultrastructural, quantitative study and correlation with hyperreactivity. Am Rev Respir Dis 1989; 140: 1745-1753.

4 Beasley R, Roche WR, Roberts JA, Holgate ST. Cellular events in the bronchi in mild asthma and after bronchial provocation. Am Rev Respir Dis 1989; 139: 806-817.

5 Laitinen LA, Laitinen A. Mucosal inflammation and bronchial hyperreactivity. Eur Respir J 1988; 1: 488-489.

6 Bradley BL, Azzawi M, Jacobson M, et al. Eosinophils, T-lymphocytes, mast cells, neutrophils, and macrophages in bronchial biopsy specimens from atopic subjects with asthma: comparison with biopsy specimens from atopic subjects without asthma and normal control subjects and relationship to bronchial hyperresponsiveness. J Allergy Clin Immunol 1991; 88: 661-674.

7 Foresi A, Bertorelli G, Pesci A, Chetta A, Olivieri D. Inflammatory markers in bronchoalveolar lavage and in bronchial biopsy in asthma during remission. Chest 1990; 98: 528-535.

8 Djukanovic R, Wilson JW, Britten KM. Quantitation of mast cells and eosinophils in the bronchial mucosa of symptomatic atopic asthmatics and healthy control subjects using immunohistochemistry. Am Rev Respir Dis 1990; 142: 863-871.

9 Poston RN, Chanez P, Lacoste JY, Litchfield T, Lee TH, Bousquet J. Immunohistochemical characterization of the cellular infiltration in asthmatic bronchi. Am Rev Respir Dis 1992; 145: 918-921.

10 Holgate ST, Wilson JR, Howarth PH. New insights into airway inflammation by endobronchial biopsy. Am Rev Respir Dis 1992; 145: S2-S6.

11 Ollerenshaw SL, Woolcock AJ. Characteristics of the inflammation in biopsies from large airways of subjects with asthma and subjects with chronic airflow limitation. Am Rev Respir Dis 1992; 145: 922-927.

12 Laitinen LA, Laitinen A, Haahtela T. Airway mucosal inflammation even in patients with newly diagnosed asthma. Am Rev Respir Dis 1993; 147: 697-704.

13 Glynn AA, Michaels L. Bronchial biopsy in chronic bronchitis and asthma. Thorax 1960; 15: 142-153.

14 Salvato G. Some histological changes in chronic bronchitis and asthma. Thorax 1968; 23: 168-172.

15 Lozewicz S, Gomez E, Ferguson H, Davies RJ. Inflammatory cells in the airways in mild asthma. BMJ 1988; 297: 1515-1516.

16 Pesci A, Foresi A, Bertorelli G, Chetta A, Olivieri D. Histochemical characteristics and degranulation of mast cells in epithelium and lamina propria of bronchial biopsies from asthmatic and normal subjects. Am Rev Respir Dis 1993; 147: 684-689.

17 Gustafsson LE. Exhaled nitric oxide as a marker in asthma. Eur Respir J 1998; 11: Suppl. 26, 49S-52S.

18 Fabbri LM, Durham S, Holgate ST, O’Byrne PM, Postma DS. Assessment of airway inflammation: an overview. Eur Respir J 1998; 11: Suppl. 26, 6S-8S.

19 Laitinen LA, Heino M, Laitinen A, Kava T, Haahtela T. Damage of the airway epithelium and bronchial reactivity in patients with asthma. Am Rev Respir Dis 1985; 131: 599-606.

20 Jeffery P, Holgate S, Wenzel S. Methods for the assessment of endobronchial biopsies in clinical research: application to studies of pathogenesis and the effects of treatment. Am J Respir Crit Care Med 2003; 168: S1-S17.

21 Jeffery PK. Investigation and assessment of airway and lung inflammation: we now have the tools, what are the questions? Eur Respir J 1998; 11: 524-528.

22 Kraft M, Martin RJ, Lazarus SC, et al. Airway tissue mast cells in persistent asthma: predictor of treatment failure when patients discontinue inhaled corticosteroids. Chest 2003; 124: 42-50.

23 Carroll NG, Mutavdzic S, James AL. Distribution and degranulation of airway mast cells in normal and asthmatic subjects. Eur Respir J 2002; 19: 879-885. 
24 Carroll N, Cooke C, James A. The distribution of eosinophils and lymphocytes in the large and small airways of asthmatics. Eur Respir J 1997; 10: 292-300.

25 Mouton PR. Principles and practices of unbiased stereology. An introduction for bioscientists. Baltimore, John Hopkins University Press, 2002.

26 Fehrenbach H, Fehrenback A, Erpenbeck VJ, et al. 2D Morphometry overestimates large relative to small inflammatory cells in human bronchial biopsies. Proceedings of the American Thoracic Society 2006; 3: A619.

27 Sterio DC. The unbiased estimation of number and sizes of arbitrary particles using the disector. J Microsc 1984; 134: 127-136.

28 Hays SR, Woodruff PG, Khashayar R, et al. Allergen challenge causes inflammation but not goblet cell degranulation in asthmatic subjects. J Allergy Clin Immunol 2001; 108: 784-790.

29 Kraft M, Djukanovic R, Wilson S, Holgate ST, Martin RJ. Alveolar tissue inflammation in asthma. Am J Respir Crit Care Med 1996; 154: 1505-1510.

30 Payne DN, Qiu Y, Zhu J, et al. Airway inflammation in children with difficult asthma: relationships with airflow limitation and persistent symptoms. Thorax 2004; 59: 862-869.

31 Howard V, Reid S, Baddeley A, Boyde A. Unbiased estimation of particle density in the tandem scanning reflected light microscope. J Microsc 1985; 138: 203-212.

32 Braendgaard H, Evans SM, Howard CV, Gundersen HJ. The total number of neurons in the human neocortex unbiasedly estimated using optical disectors. J Microsc 1990; 157: 285-304.

33 Gundersen HJ. Stereology of arbitrary particles. A review of unbiased number and size estimators and the presentation of some new ones, in memory of William R. Thompson. J Microsc 1986; 143: 3-45.

34 Carroll NG, Mutavdzic S, James AL. Increased mast cells and neutrophils in submucosal mucous glands and mucus plugging in patients with asthma. Thorax 2002; 57: 677-682.

35 Bai A, Eidelman DH, Hogg JC, et al. Proposed nomenclature for quantifying subdivisions of the bronchial wall. $J$ Appl Physiol 1994; 77: 1011-1014.

36 Howard CV, Reed MG. Unbiased Stereology. 2nd Edn. New York, Bios Scientific, Springer Verlag, 2005.

37 Sont JK, Willems LN, Evertse CE, Hooijer R, Sterk PJ, van Krieken JH. Repeatability of measures of inflammatory cell number in bronchial biopsies in atopic asthma. Eur Respir J 1997; 10: 2602-2608.

38 Sullivan P, Stephens D, Ansari T, Costello J, Jeffery P. Variation in the measurements of basement membrane thickness and inflammatory cell number in bronchial biopsies. Eur Respir J 1998; 12: 811-815.
39 Gamble E, Burns W, Zhu J, et al. Variation of CD8+ T-lymphocytes around the bronchial internal perimeter in chronic bronchitis. Eur Respir J 2003; 22: 992-995.

40 Gamble E, Qiu Y, Wang D, et al. Variability of bronchial inflammation in chronic obstructive pulmonary disease: implications for study design. Eur Respir J 2006; 27: 293-299.

41 ten Hacken NH, Aleva RM, Oosterhoff Y, et al. Submucosa $1.0 \times 0.1 \mathrm{~mm}$ in size is sufficient to count inflammatory cell numbers in human airway biopsy specimens. Mod Pathol 1998; 11: 292-294.

42 De Boer WI, Hiemstra PS, Sont JK, et al. Image analysis and quantification in lung tissue. Clin Exp Allergy 2001; 31: 504-508.

43 Curull V, Orozco-Levi M, Moyes D, et al. [Fiber-optic bronchoscopic biopsy of bronchial smooth muscle. Efficacy of the technique in individuals with normal lung function and patients with COPD]. Arch Bronconeumol 2002; 38: 515-522.

44 Brightling CE, Bradding $\mathrm{P}$, Symon FA, Holgate ST, Wardlaw AJ, Pavord ID. Mast-cell infiltration of airway smooth muscle in asthma. $N$ Engl J Med 2002; 346: 1699-1705.

45 Bolender RP, Hyde DM, Dehoff RT. Lung morphometry: a new generation of tools and experiments for organ, tissue, cell, and molecular biology. Am J Physiol 1993; 265: L521-L548.

46 Schulman ES, Pollack RB, Post TJ, Peters SP. Histochemical heterogeneity of dispersed human lung mast cells. J Immunol 1990; 144: 4195-4201.

47 Brightling CE, Bradding $\mathrm{P}$. The re-emergence of the mast cell as a pivotal cell in asthma pathogenesis. Curr Allergy Asthma Rep 2005; 5: 130-135.

48 Prussin C, Metcalfe DD. 4. IgE, mast cells, basophils, and eosinophils. J Allergy Clin Immunol 2003; 111: Suppl. 2, S486-S494.

49 Robinson DS. The role of the mast cell in asthma: induction of airway hyperresponsiveness by interaction with smooth muscle? J Allergy Clin Immunol 2004; 114: 58-65.

50 Ammit AJ, Bekir SS, Johnson PR, Hughes JM, Armour CL, Black JL. Mast cell numbers are increased in the smooth muscle of human sensitized isolated bronchi. Am J Respir Crit Care Med 1997; 155: 1123-1129.

51 Elliot JG, Jensen CM, Mutavdzic S, Lamb JP, Carroll NG, James AL. Aggregations of lymphoid cells in the airways of nonsmokers, smokers, and subjects with asthma. Am J Respir Crit Care Med 2004; 169: 712-718.

52 Berger P, Walls AF, Marthan R, Tunon-de-Lara JM. Immunoglobulin E-induced passive sensitization of human airways: an immunohistochemical study. Am J Respir Crit Care Med 1998; 157: 610-616. 